\title{
ANAESTHETIC MANAGEMENT OF A CASE OF XERODERMA PIGMENTOSUM WITH SQUAMOUS CELL CARCINOMA POSTED FOR WIDE EXCISION AND GRAFTING PRESENTING WITH A DIFFICULT AIRWAY
}

Shahedha Parveen1, M. Santhisree², P. Krishna Prasad 3 , B. Sowbaghya Lakshmi

\section{HOW TO CITE THIS ARTICLE:}

Shahedha Parveen, M. Santhisree, P. Krishna Prasad, B. Sowbaghya Lakshmi. "Anaesthetic Management of a Case of Xeroderma Pigmentosum with Squamous Cell Carcinoma Posted for Wide Excision and Grafting Presenting with a difficult Airway". Journal of Evolution of Medical and Dental Sciences 2015; Vol. 4, Issue 03, January 08; Page: 476-480, DOI: 10.14260/jemds/2015/69

ABSTRACT: BACKGROUND: Xeroderma Pigmentosum (XP) is a rare autosomal recessive disorder characterized by hypersensitivity of the skin to UV radiation. These patients show a failure to repair UV induced DNA lesions caused by Nucleotide Excision Repair mechanism. They develop neoplasms at an early age and require repeated surgeries. METHODOLOGY: We report an 18 year old female patient with XP who presented with squamous cell carcinoma over parotidectomy site and was scheduled for wide excision and skin grafting. During Pre anesthetic checkup, difficult air way was anticipated and so all the available airway gadgets were kept ready. General anesthesia with propofol was planned. OBSERVATION: After adequate preparation, counseling regarding anesthetic plan of action and high risk consent, propofol given followed by succinylcholine. Patient had severe restriction of mouth opening when compared to preoperative period probably due to masseter spasm after succinylcholine. Placing an I-Gel by an experienced anesthesiologist helped in the successful management of this case. CONCLUSION: Newer supraglottic devices like I-Gel may be considered as a safer alternative in such difficult situations.

KEYWORDS: Xeroderma Pigmentosum, Anesthetic Implications, Difficult Airway, Difficult Mask Adaptation, I-Gel.

INTRODUCTION: Xeroderma Pigmentosum ${ }^{1}$ is a rare autosommal recessive disorder characterized by hypersensitivity to sunlight, occular involvement and progressive neurological complications. ${ }^{2}$ These manifestations are due to UV radiation leading to a defect in repair of DNA by process of nucleotide excision repair (NER). Though XP induced changes are predominantly dermatological they develop premature neoplasm, ${ }^{3,4}$ face repeated surgical insults due to poor healing and thus pose several challenges to the anesthetist.

CASE REPORT: An 18 years old girl, weighing $40 \mathrm{~kg}$ with XP had squamous cell carcinoma over the surgical (Post parotidectomy) site and was posted for wide excision and skin grafting. During the preanesthetic evaluation, she was appearing very calm and able to provide the history from the onset of this skin disease since 8 months of her childhood and the complications she had faced (Dermal, occular, neurological and neoplastic of the present surgery) [Fig-1]. 0/e-She was poorly built and nourished had generalized b/l distributed freckles, hypopigmented nodules over the face, trunk and extremities, hypopigmented nodules over the lips, left conjunctiva was congested, cornea was hazy and watering present from that eye. Systemic examination was normal. Investigations (Blood routine, ECG and CXR) were within normal range. Preoperative vitals were checked and found stable. 


\section{CASE REPORT}

Airway Assessment: Temporomandibular mobility assessed by -bite test (Lower jaw teeth bite upper lip vermillion on protrusion) and ability to open the mouth (Inter Incisor distance was approximately $1.5 \mathrm{~cm}$ Both were restricted in our patient. Thyromental distance $>6 \mathrm{~cm}$. Mallampatti class IV. Cervical spine movements were possible in all directions. Difficult airway was anticipated though she had been previously intubated with ease as revealed from her previous anesthetic record. Under ASA Physical status Gr1 with a difficult airway, she was accepted after high risk, written and informed consent. Mild sedative - Tablet Alprazolam 0.25 mg and Tab Ranitidine 150mg were given night before surgery. NPO orders issued.

On arrival in the Operation Theatre IV cannula was very carefully secured, multipara monitor (ECG, NIBP, SPO2, Et Co2) was attached, basal parameters recorded NIBP 112/75 mm/hg, Sp 02 98\%, HR - 86bpm. Difficult airway equipment ie. bougie, styleted endotracheal tubes 7.0, 6.5 sizes, LMA classic size 3, LMA proseal, Igel size 3 and tracheostomy kits 7.0, 6.5 were kept ready. [Fig-2]. Premedication given with inj. Glycopyrolate $0.2 \mathrm{mg}$ and Fentanyl $1 \mathrm{mcg} / \mathrm{kg}$ iv, inj Xylocard $1.5 \mathrm{mg} / \mathrm{kg}$ iv given. Mask was gently applied superficially taking care not to traumatize cutaneous nodules surrounding the nose and mouth. After adequate preoxygenation for 5mins, patient induced with Propofol $2 \mathrm{mg} / \mathrm{kg}$ and relaxant succinylcholine $1.5 \mathrm{mg} / \mathrm{kg} \mathrm{mg}$ administered. Fasciculations followed by flaccid paralysis noted and approximately $45 \mathrm{sec}$ later jaw relaxation was looked for but in vain.

It appeared to be very rigid, probably due to severe masseter spasm, unable to insinuate even a single finger. We had to resort to I- Gel [Fig-3]. It could be placed successfully with a little difficulty as the tongue was dropping back obstructing the pathway. We had to lift the tongue using Magills forceps and then slipped the I-Gel into place with little force and connected to Bain Circuit. Chest lift was visualized and ventilation was adequate. Atracurium was given after the patient showed signs of recovery from suxamethonium and carefully head turned to the right by the surgeon. I-gel insitu, ventilation was adequate. Rest of the procedure was uneventful [Fig-4].

Patient had Modified Aldrete Recovery score 10, with adequate respiratory efforts and stable vitals, hence I-Gel was removed on table. Post-operative analgesia was given with low dose Fentanyl and IV Paracetomol 500mg.

DISCUSSION: Incidence of XP is 1in 2, 50, 000 births in USA, 1 in 20, 000 in Japan ${ }^{5}$ and rare in blacks. It causes premature neoplasms especially in head, neck and face. They have ulcerating skin nodules, requiring repeated surgeries and have high incidence of graft failure as well.

The major anesthetic concerns are psychological, sociological impact on patients and relatives due to repeated exposure to surgery and anesthesia, pigmented skin hinders visualization, cannulation and fixation of venous access and various non-invasive monitoring techniques. XP demands eye care and protection of patient from artificial light, well padding of pressure points and movements should be gentle to prevent skin injuries. Head \& neck lesions lead to difficult face mask adaptation, difficult laryngoscopy and intubation. Presence of variable neurological abnormalities is very challenging in choosing induction agents, muscle relaxants and regional anesthesia techniques.

They are also sensitive to synergistic effects of opioids and benzodiazepines due to immature brain development In Masuda et.al ${ }^{6}$ study avoided nitrous oxide because 5 flurouracil can cause myelosuppression and avoided inhalational agents such as halothane, ${ }^{7}$ isoflurane, ${ }^{8}$ sevoflurane ${ }^{9}$ as they cause genotoxic effects and damage NER in cells. T.I.V.A technique using propofol and fentanyl is reported by Miyazaki. et.al study. ${ }^{10}$ 
Oliveira et.al ${ }^{11}$ study showed that minimum usage of muscle relaxants under monitoring of neuromuscular block is ideal in patients of XP due to neuronal dysfunction, skin atrophy and joint contracture. As it is a difficult airway, but previously intubated we had given succinylcholine 60mg. probably due to masseter spasm added to post-operative fibrosis, we had severe restriction in mouth opening. I- gel was the safest device that could be dwelled in with ease without the aid of a finger. Masseter spasm ${ }^{12}$ has been implicated as an early indicator of susceptibility for malignant hyper thermia (MH). But other markers like hyperpyrexia, increased ETCO2, generalized rigidity, autonomic instability and rhabdomyoloysis were not seen in our case. The incidents of $\mathrm{MH}$ are unknown in adults with masseter spasm although isolated masseter spasm is not pathognomic for MH. I - gel is a second generation supraglottic airway device with non-inflatable cuff for use in anesthesia. ${ }^{13}$

Advantages: Quick, easy and reliable to insert. High seal pressure, reduced trauma, used for routine anesthesia. Incorporates a gastric channel to provide additional protection against aspiration. Has the versatility to be applicable for use during Difficult Airway Management, ${ }^{14}$ as a rescue device and a conduit for intubation. Internal bite block reduced the possibility for airway channel occlusion.

Virtually eliminates rotation. What makes it unique is the material from which it is made i.e. medical grade thermo plastic elastomer, so that it works in harmony with patient anatomy by creating high pressure seal of pharyngeal, laryngeal and perilaryngeal structures. I Gel is chosen based on manufacturers recommendation on body weight basis. The ease of insertion was graded from 1 (very easy) to 5 (Very difficult). Success was defined as ability to deliver adequate tidal volumes and insertion of the device. Failure due to tongue fall and misplacement. ${ }^{15}$

CONCLUSION: Use of I gel made this procedure safe, easy even in altered head position, reduced drug requirements and reduced post-operative complications. XP patients may come for repeated surgeries and anesthetist must pay meticulous attention to the airway especially when GA is administered. This case report may pave the way for future research in using this technique in such difficult situations, ${ }^{16}$ especially useful in resource limited setting.

\section{REFERENCES:}

1. Lehmann AR, McGibbon D, Stefanini M. Xeroderma pigmentosum. Orphanet J Rare Dis. 2011; 6: 70.

2. Kraemer KH, Lee MM, Scotto J. Xeroderma pigmentosum. Cutaneous, ocular, and neurologic abnormalities in 830 published cases. Arch Dermatol. 1987; 123 (2): 241-50.

3. Brunner T, Johr M. Anesthetic management of a child with xeroderma pigmentosum. Paediatr Anaesth. 2004; 14 (8): 697-8.

4. Mulimani SM, Talikoti DG. A child with xeroderma pigmentosum for excision of basal cell carcinoma. Saudi J Anaesth. 2013; 7 (4): 467-9.

5. Feller L, Wood NH, Motswaledi MH, Khammissa RA, Meyer M, Lemmer J. Xeroderma pigmentosum: a case report and review of the literature. J Prev Med Hyg. 2010; 51 (2): 87-91.

6. Masuda Y, Imaizumi H, Okanuma M, Narimatsu E, Asai Y, Namiki Anesthesia for a patient with xeroderma pigmentosum. Masui. 2002; 51 (2): 169-71. 


\section{CASE REPORT}

7. Reitz M, Lanz E. DNA strand breaks in cells with DNA repair deficiency after halothane exposure in vitro. Arzneimittelforschung. 1993; 43 (4): 418-20.

8. Karabiyik L, Sardas SN, Polat U, Kocaba S, Karakaya AE. Comparison of genotoxicity of sevoflurane and isoflurane in human lymphocytes studied in vivo using the comet assay. Mutat Res. 2001; 492 (1-2): 99-107.

9. Fjouji S, Bensghir M, Yafat B, Bouhabba N, Boutayeb E, Azendour H, et al. Postoperative neurological aggravation after anesthesia with sevoflurane in a patient with xeroderma pigmentosum: a case report. J Med Case Rep. 2013; 7(1): 73.

10. Miyazaki R, Nagata T, Kai T, Takahashi S. Anesthesia for a patient with xeroderma pigmentosum. Masui. 2007; 56 (4): 439-41.

11. Oliveira CR, Elias L, Barros AC, Conceicao DB. Anesthesia in patient with Xeroderma Pigmentosum: Case report. Rev Bras Anes tensiol. 2003; 53 (1): 46-51.

12. Vendor speak AF, reynold p.Fang WB.et.al changes in resistance to mouth opening induced by depolarizing an non depolarising nemomuscular relaxants. Br J.Anesth. 1990, 64-21-7.

13. Siddiqui AS, Ahmed J, Siddiqui SZ, Haider S, Raza SA. J Coll Physicians Surg Pak. New single use supraglottic airway device with non-inflatable cuff and gastric tube channel 2012 Jul; 22(7): 419-23.

14. Emmerich $\mathrm{M}^{1}$, Dummler R. Use of I-gel laryngeal mask for management of a difficult airway Anesthetist, 2008. Aug. 57(8) 779-81.

15. Michalek P, Doneldson W J, Hinds J D. Tongue trauma associated with i-gel supraglottic airway Anesthesia June 2009,:64(6);692-693.

16. Asai T. Successful use of I-gel in three patients in difficult intubation and difficult ventilation. Masui 2011 July, 60(7); 850-2.

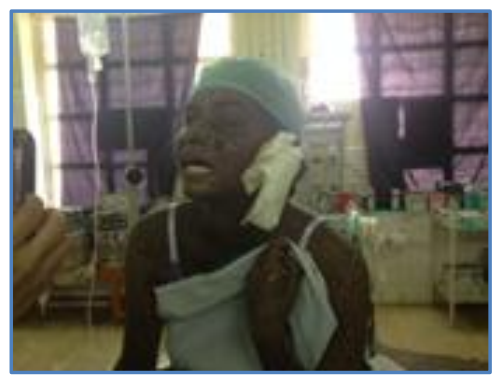

Fig. 1: XP- Mallampatti IV

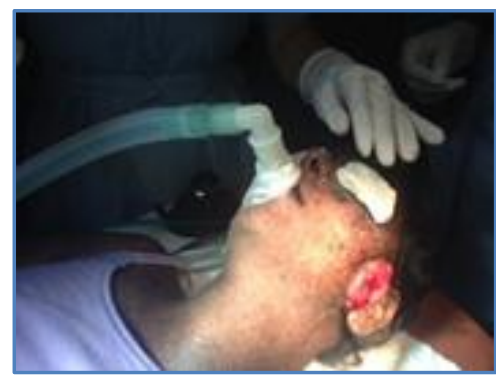

Fig. 3 I-gel insitu

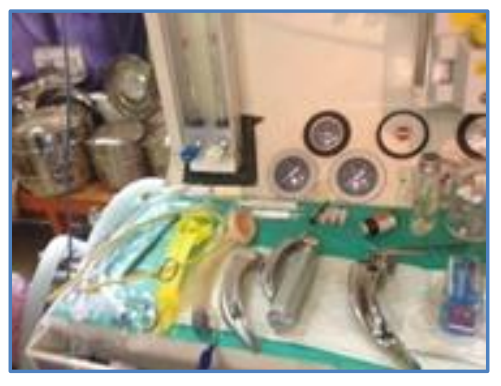

Fig. 2: Airway equipment

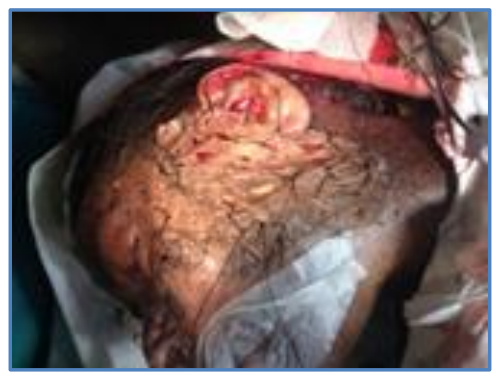

Fig. 4: Post grafting 


\section{AUTHORS:}

1. Shahedha Parveen

2. M. Santhisree

3. P. Krishna Prasad

4. B. Sowbaghya Lakshmi

\section{PARTICULARS OF CONTRIBUTORS:}

1. Assistant Professor, Department of Anaesthesiology, Rangaraya Medical College.

2. Assistant Professor, Department of Anaesthesiology, Rangaraya Medical College.

3. Associate Professor, Department of Anaesthesiology, RMC.

4. Professor and HOD, Department of Anaesthesiology, Rangaraya Medical College, Kakinada.

\section{NAME ADDRESS EMAIL ID OF THE CORRESPONDING AUTHOR: \\ Dr. Shahedha Parveen, Assistant Professor, Department of Anaesthesiology, Rangaraya Medical College, \\ D. No. 21-3-23, Salipeta, Kakinada-533001. \\ E-mail: drshahedha@gmail.com}

Date of Submission: 23/12/2014. Date of Peer Review: 24/12/2014. Date of Acceptance: 31/12/2014. Date of Publishing: 07/01/2015. 